\title{
A NÉPESSÉGSZÁM VÁLTOZÁS TELEPÜLÉSI ÉS MEGYEI SZINTŰ EGYENLŐTLENSÉGEINEK NÉHÁNY MÉRÉSI LEHETŐSÉGE MAGYARORSZÁGON ${ }^{1}$
}

\section{(Some Quantitative Methods Measuring the Disequalities of the Population Change in the Hungarian Settlements and Counties)}

\section{BAJMÓCY PÉTER}

Kulcsszavak:

népességszám-változás Magyarország települései kvantitatív módszerek

A népességszám-változás terilleti különbségei ugyan jól ismertek Magyarországon, ám néhány kvantitatív módszer segítségével újabb adalékok adhatók e témához csupán a telepuilések vándorlási egyenlege, népességszám-változása segítségével is. A legtöbb mutató a szuburbanizáció létét erősíti meg Budapest és a nagyvárosok körüll, és e tekintetben is számottevö a fởváros elönye a nagyvárosok környékéhez képest.

E tanulmány célja, hogy néhány egyszerú kvantitatív módszer segítségével újabb adalékokat adjon egy többé-kevésbé ismert téma, Magyarország településeinek népességszám-változása témaköréhez. E tanulmányban kizárólag a népességszámváltozás legfontosabb összetevőivel, a természetes szaporodással, a vándorlási egyenleggel, illetve a tényleges szaporodással foglalkozunk. A KSH települési szintủ adatait vizsgáltuk, ezekbỏl néhány esetben megyei szintủ aggregációkat készítettünk. Tanulmányunk célja néhány egyszerủ kvantitatív módszer próbája, így három, részben összefüggő, részben különálló vizsgálatot végeztünk el.

\section{1. módszer: Kombináció}

Az ország települései népességszám-változásának területi különbségei ismertek (Beluszky-Sikos T 1982; Beluszky 1999; Bajmócy 1999; 2000). Jól kirajzolódnak a nagyvárosok körüli dinamikus zónák középpontjukban a fogyó nagyvárossal (Tímár 1993), valamint egyes kisebb dinamikus térségek a Balaton, a nyugati határmente vagy éppen egyes gyógyfürdök közelében (1. ábra). Ugyanakkor számos település népességnövekedéssel jellemezhető a perifériákon is (Borsod-Abaúj-Zemplén, Szabolcs-Szatmár-Bereg, Baranya).

Ez utóbbi települések némelyikénél a népességnövekedésének oka nem a többi település esetében elsődleges vándorlási egyenleg, hanem a természetes szaporodás. A vándorlási egyenleg térbelisége számos esetben hasonlít ą elözỏekhez (2. ábra), ám néhány, idősek otthonával rendelkező község esetében szintén jelentős vándorlási egyenleggel számolhatunk. Érdemesnek tủnt tehát e két mutatót, a népességszám-változást, illetve a vándorlási egyenleget kombinálni. 
Bajmócy Péter : A népességszám változás települési és megyei szintű egyenlőtlenségeinek néhány mérési lehetösége Magyarországon. Tér és Társadalom 21. évf. 2007/1. 85-102. p.

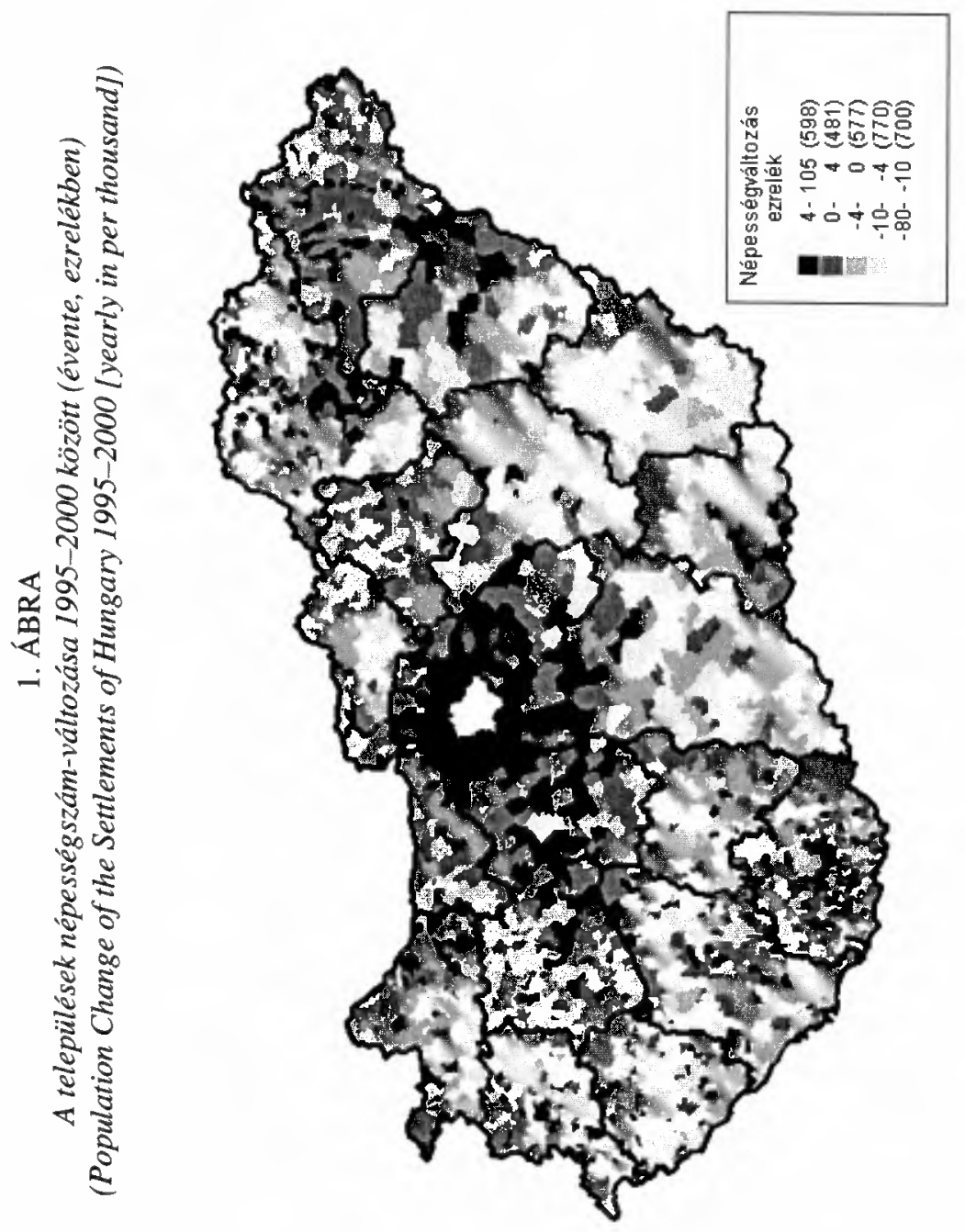

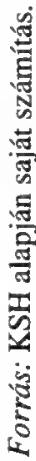


Bajmócy Péter : A népességszám változás települési és megyei szintū egyenlőtlenségeinek néhány mérési lehetösége Magyarországon. Tér és Társadalom 21. évf. 2007/1. 85-102. p.

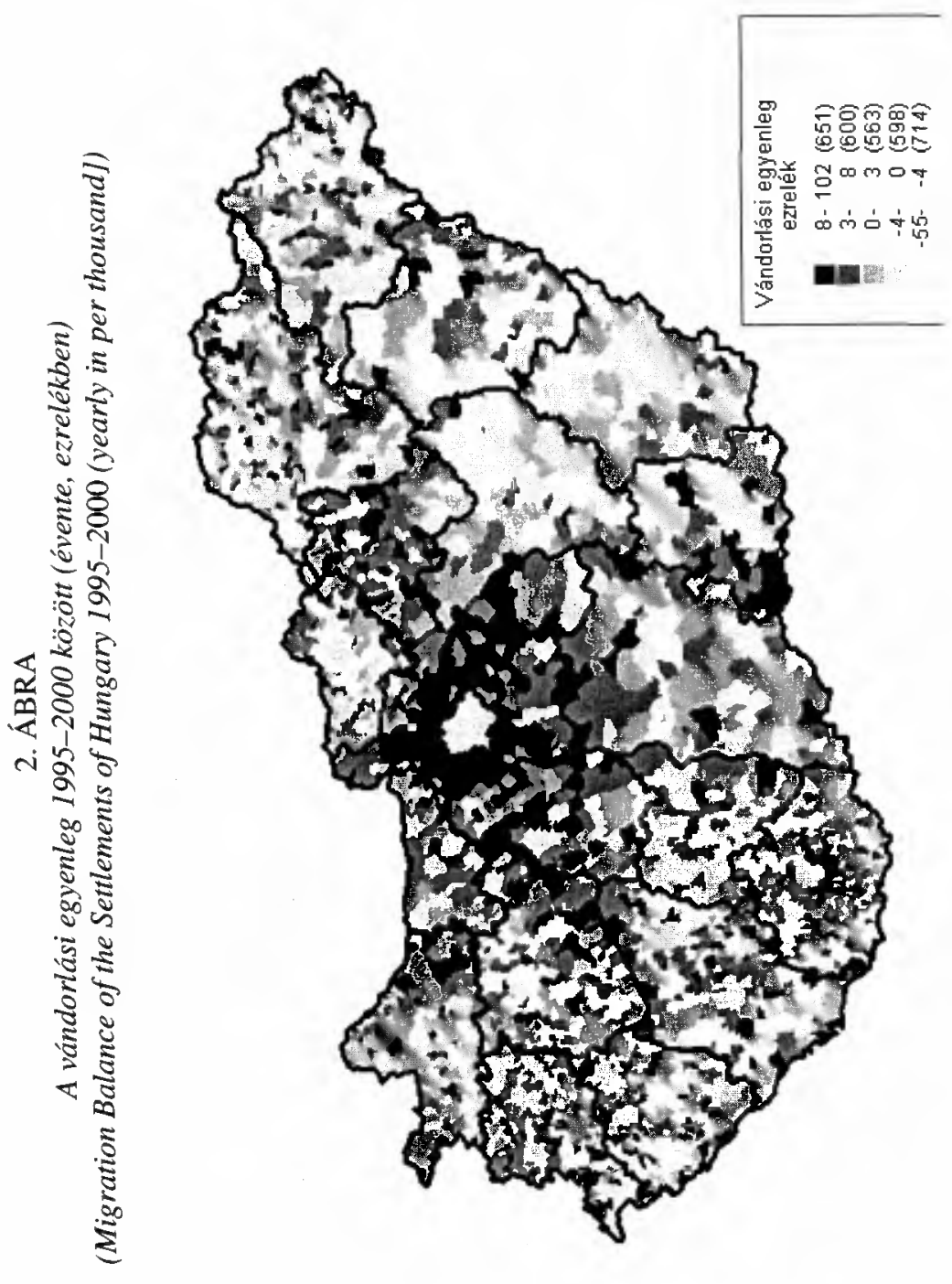

宽 
Bajmócy Péter : A népességszám változás települési és megyei szintū egyenlőtlenségeinek néhány mérési lehetösége Magyarországon. Tér és Társadalom 21. évf. 2007/1. 85-102. p.

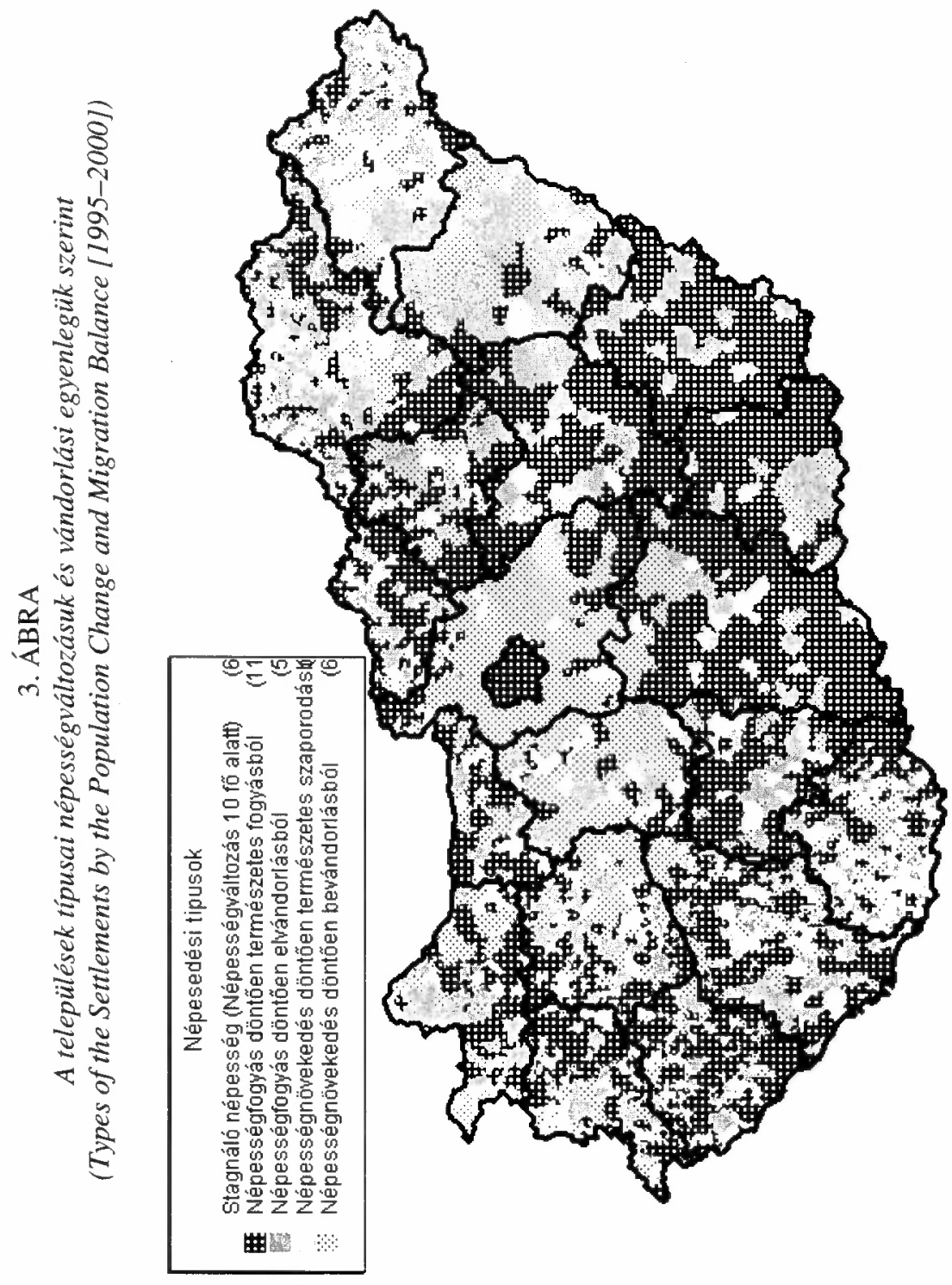


Bajmócy Péter : A népességszám változás települési és megyei szintü egyenlötlenségeinek néhány mérési lehetösége Magyarországon. Tér és Társadalom 21. évf. 2007/1. 85-102. p.

Egy egyszerü településtipizálás segítségével az ország településeit öt csoportra osztottuk az 1995-2000 közötti népességszám-változásuk és vándorlási egyenlegük szerint. Az elhatárolt típusok a következök:

- 1. típus: növekvő népességü települések, ahol a növekedés oka elsősorban a vándorlási nyereség,

- 2. típus: növekvő népességü települések, ahol a növekedés oka elsősorban a természetes szaporodás,

- 3. típus: fogyó népességủ települések, ahol a fogyás oka elsösorban a vándorlási veszteség,

- 4. típus: fogyó népességủ települések, ahol a fogyás oka elsősorban a természetes fogyás,

- 5. típus: stagnáló népességú települések, ahol a népességszám-változás 19952000 között nem haladta meg a \pm 10 föt.

\section{TÁBLÁZAT}

A települések megoszlása vándorlási egyenleg és tényleges szaporodás szerinti típusokban, a megyék településállományához viszonyítva, 1995-2000

(Distribution of the Settlemnts by Counties and by their Population Change and Migration Balance [1995-2000])

\begin{tabular}{|c|c|c|c|c|c|c|c|c|c|c|c|}
\hline \multirow{3}{*}{ Megye } & \multicolumn{6}{|c|}{ Települések száma } & \multicolumn{5}{|c|}{ Települések aránya } \\
\hline & & az 1. & $a 2$. & $a 3$. & $a 4$. & $\begin{array}{l}a z \\
5 .\end{array}$ & $\begin{array}{l}a z \\
1 .\end{array}$ & $\begin{array}{l}a \\
2 .\end{array}$ & $\begin{array}{l}a \\
3 .\end{array}$ & $\begin{array}{l}a \\
4 .\end{array}$ & $\begin{array}{c}a z \\
5 .\end{array}$ \\
\hline & $\begin{array}{c}\text { össze- } \\
\text { sen }\end{array}$ & \multicolumn{5}{|c|}{ tipusban } & \multicolumn{5}{|c|}{ tipusban (\%) } \\
\hline BAR & 302 & 55 & 11 & 59 & 66 & 111 & 18 & 4 & 20 & 22 & 37 \\
\hline BKK & 117 & 12 & 0 & 12 & 82 & 11 & 10 & 0 & 10 & 70 & 9 \\
\hline BEK & 75 & 3 & 0 & 15 & 53 & 4 & 4 & 0 & 20 & 71 & 5 \\
\hline $\mathrm{BAZ}$ & 355 & 55 & 32 & 81 & 108 & 79 & 16 & 9 & 23 & 30 & 22 \\
\hline CSN & 59 & 13 & 0 & 6 & 34 & 6 & 22 & 0 & 10 & 58 & 10 \\
\hline FEJ & 106 & 58 & 2 & 10 & 19 & 17 & 55 & 2 & 9 & 18 & 16 \\
\hline GMS & 173 & 42 & 1 & 29 & 67 & 34 & 24 & 1 & 17 & 39 & 20 \\
\hline $\mathrm{HBH}$ & 82 & 23 & 6 & 28 & 19 & 6 & 28 & 7 & 34 & 23 & 7 \\
\hline $\mathrm{HEV}$ & 118 & 29 & 2 & 10 & 59 & 18 & 25 & 2 & 9 & 50 & 15 \\
\hline KOE & 73 & 23 & 1 & 7 & 27 & 15 & 32 & 1 & 10 & 37 & 21 \\
\hline NOG & 127 & 8 & 2 & 25 & 73 & 19 & 6 & 2 & 20 & 58 & 15 \\
\hline PST & 185 & 141 & 1 & 2 & 26 & 15 & 76 & 1 & 1 & 14 & 8 \\
\hline SOM & 243 & 40 & 5 & 54 & 93 & 51 & 17 & 2 & 22 & 38 & 21 \\
\hline SSB & 228 & 46 & 31 & 51 & 38 & 62 & 20 & 14 & 22 & 17 & 27 \\
\hline JNS & 78 & 7 & 2 & 11 & 48 & 10 & 9 & 3 & 14 & 62 & 13 \\
\hline TOL & 108 & 12 & 1 & 25 & 56 & 14 & 11 & 1 & 23 & 52 & 13 \\
\hline VAS & 216 & 31 & 1 & 29 & 88 & 67 & 14 & 1 & 13 & 41 & 31 \\
\hline VES & 223 & 46 & 0 & 42 & 78 & 57 & 21 & 0 & 19 & 35 & 26 \\
\hline $\mathrm{ZAL}$ & 257 & 28 & 0 & 38 & 119 & 72 & 11 & 0 & 15 & 46 & 28 \\
\hline Összesen & 3125 & 672 & 98 & 534 & 1153 & 668 & 22 & 3 & 17 & 37 & 21 \\
\hline
\end{tabular}

Forrás: Saját számítás a KSH adatai alapján. 
Bajmócy Péter : A népességszám változás települési és megyei szintü egyenlötlenségeinek néhány mérési lehetösége Magyarországon. Tér és Társadalom 21. évf. 2007/1. 85-102. p.

E településtípusok igen egyenetlenül helyezkednek el az ország területén (1. táblázat). A szuburbanizáció által érintett községek túlnyomó többsége az 1. típusba tartozik (3. ábra). A korábbi évtizedekben jelentős elvándorlással sújtott, így elöregedett megyék (Bács-Kiskun, Békés, Csongrád, Jász-Nagykun-Szolnok, Heves, Nógrád és Tolna) a 4. típus dominanciájával jellemezhetők. Ugyanakkor Hajdú-Bihar SzabolcsSzatmár-Bereggel és Borsod-Abaúj-Zemplénnel egy másik kategóriát alkot, ahol a magasabb természetes szaporodás (mérsékeltebb fogyás) következtében a 2. és a 3. típus aránya haladja meg jelentősen az országos átlagot. Emellett még három másik kategória jelentkezett. A gazdaságilag prosperáló, illetve a szuburbanizáció által leginkább érintett Pest és Fejér megyékben az 1. típus dominál, a többi dunántúli megyében pedig az aprófalvas településszerkezetük következtében az 5. típus emelkedik ki. E típus mellett Baranyában és Somogyban a 2. és 3. is jelentős (roma kisebbség), ugyanakkor Györ-Moson-Sopron, Komárom-Esztergom, Veszprém, Vas és Zala megyékben pedig a 4. típus is számottevő, elsősorban e megyék periférikus térségeiben (Bársonyos, Rábaköz, Bakonyalja, Kemeneshát, Dél-Zala).

\section{2. módszer: Hol vannak, milyen típusúak a növekvö népességü települések?}

Területileg természetesen ismert a növekvő népességszámú települések elhelyezkedése, ugyanakkor azt is láttuk, hogy a növekvő népességü települések igen különböző típusúak. Hogyan lehet azt mérni, hogy mekkora a szerepe a népességnövekedésben a szuburbanizációnak, ezen belül a Budapest-környékének, mekkora a természetes szaporodásnak, a turizmusnak stb? E kérdések eldöntéséhez szükség van a települések tipizálására.

Az egyes települések megfelelö típusba osztása nem volt egyszerü feladat, ennek eldöntésére korábbi tapasztalatainkat, a települések különböző társadalmi jellemzőit, fekvésüket vettük figyelembe. A népességszám-változás abszolút értékeit vizsgálva nem történt komoly területi átrendeződés az 1990-es évek második fele és a 2000-es évtized elsỏ évei között. (4. ábra, 5. ábra). Miközben az ország népességfogyása valamelyest mérséklödött a vizsgált két idöszak (1995-1999 és 2001-2004) között (2. táblázat), a növekvő népességszámú települések száma lényegileg változatlan maradt. Ugyanakkor nött a települések differenciáltsága a népességszámváltozásokat tekintve, hiszen a népességüket növelö települések népességnövekménye jelentösen nagyobb lett 2001-2004-re (28 508 fö évente) 1995-1999-hez képest (22 437 fö). Nemcsak a népességnövekmény, de a népességüket relatíve gyorsan (évente legalább 10 fövel) növelö települések száma is emelkedett. E gyorsan növekvő településcsoport (mely a növekvő népességszámú települések 42-45\%-át adja) koncentrálja az összes növekvő népességü település népességnövekményének 90-92\%-át, S ez az érték valamelyest emelkedett is 2001-2004-re 1995-1999-hez képest. 
Bajmócy Péter : A népességszám változás települési és megyei szintū egyenlőtlenségeinek néhány mérési lehetösége Magyarországon. Tér és Társadalom 21. évf. 2007/1. 85-102. p.

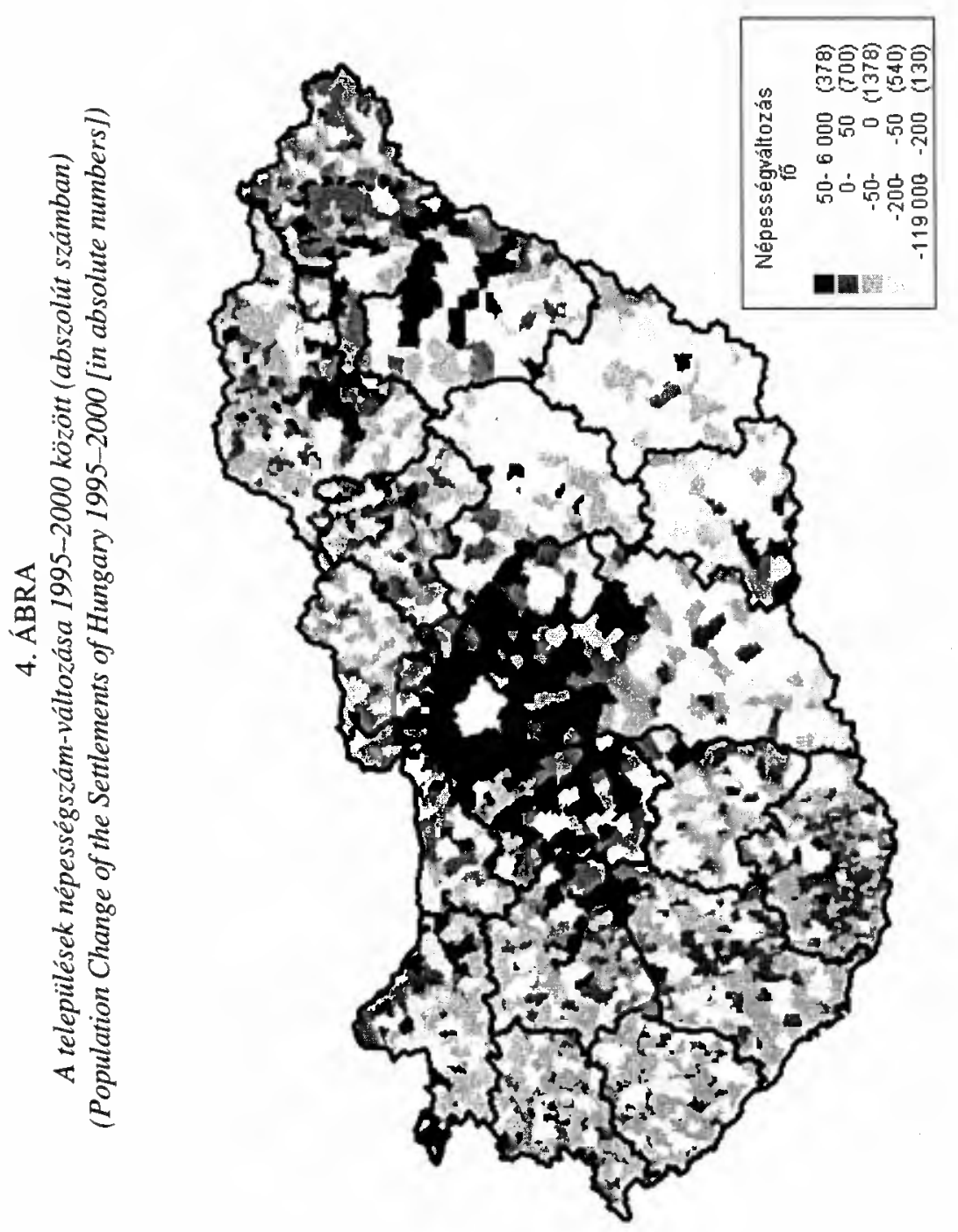


Bajmócy Péter : A népességszám változás települési és megyei szintü egyenlötlenségeinek néhány mérési lehetősége Magyarországon. Tér és Társadalom 21. évf. 2007/1. 85-102. p.

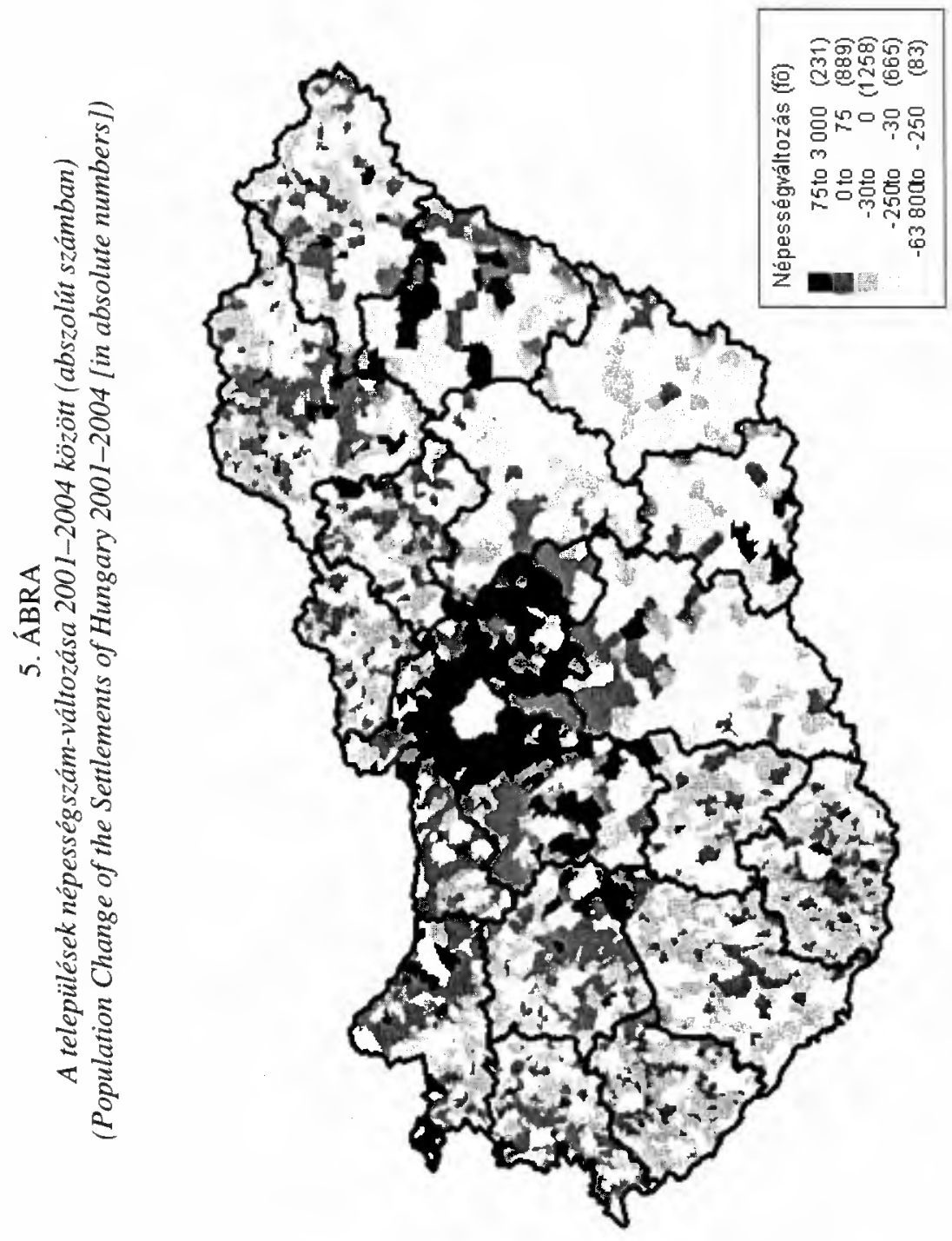

总 
Bajmócy Péter : A népességszám változás települési és megyei szintü egyenlötlenségeinek néhány mérési lehetösége Magyarországon. Tér és Társadalom 21. évf. 2007/1. 85-102. p.

TÉT XXI. évf. 2007 -

A népességszám változás települési és... 93

\section{TÁBLÁZAT}

Az abszolút számban növekvó települések néhány adata 1995-1999, illetve 2001-2004 között (évente)

(Some Data of the Settlements with Increasing Population between 1995-1999 and 2001-2004 [yearly])

\begin{tabular}{lrc}
\hline & $1995-1999$ & $2001-2004$ \\
\hline Éves népességszám-változás & -41697 & -37881 \\
A növekvő települések száma & 1046 & 1040 \\
A növekvő települések növekedése (évente, fő) & 22437 & 28508 \\
Települések legalább 10 fös évenkénti átlagos & 437 & 472 \\
népességnövekedéssel & & \\
A 10 fö felettiek növekménye (fö) & 20196 & 26084 \\
A 10 fö felettiek növekménye (\%) & 90,2 & 91,5 \\
\hline
\end{tabular}

Forrás: Sajắt számítás a KSH adatai alapján.

\section{TÁBLÁZAT}

Az abszolút számban növekvö települések néhány adata 1995-1999, illetve 2001-2004 között (évente), megyénként

(Some Data of the Settlements with Increasing Population between 1995-1999 and 2001-2004 [yearly, by counties])

\begin{tabular}{|c|c|c|c|c|c|}
\hline Megye & $\begin{array}{c}\text { Növek- } \\
\text { mény } \\
1995- \\
1999\end{array}$ & $\begin{array}{c}\text { Növek- } \\
\text { mény } \\
2001- \\
2004\end{array}$ & $\begin{array}{c}\text { Változás } \\
(\%)\end{array}$ & $\begin{array}{c}\text { Részarány } \\
\text { az orszá- } \\
\text { gosból } \\
1995- \\
1999 \\
\end{array}$ & $\begin{array}{c}\text { Részarány } \\
\text { az orszá- } \\
\text { gosból } \\
2001- \\
2004\end{array}$ \\
\hline Baranya & 631 & 980 & 155,3 & 2,8 & 3,4 \\
\hline Bács-Kiskun & 455 & 328 & 72,0 & 2,0 & 1,1 \\
\hline Békés & 31 & 16 & 51,2 & 0,1 & 0,1 \\
\hline Borsod-A.-Zemplén & 1269 & 1272 & 100,2 & 5,7 & 4,5 \\
\hline Csongrád & 476 & 542 & 113,9 & 2,1 & 1,9 \\
\hline Fejér & 1497 & 1727 & 115,4 & 6,7 & 6,1 \\
\hline Györ-Moson-Sopron & 723 & 1634 & 225,9 & 3,2 & 5,7 \\
\hline Hajdú-Bihar & 930 & 940 & 101,1 & 4,1 & 3,3 \\
\hline Heves & 365 & 437 & 119,8 & 1,6 & 1,5 \\
\hline Komárom-Esztergom & 437 & 647 & 148,3 & 1,9 & 2,3 \\
\hline Nógrád & 72 & 357 & 493,7 & 0,3 & 1,3 \\
\hline Pest & 11941 & 15968 & 133,7 & 53,2 & 56,0 \\
\hline Somogy & 493 & 494 & 100,1 & 2,2 & 1,7 \\
\hline Szabolcs-Sz.-Bereg & 1112 & 557 & 50,1 & 5,0 & 2,0 \\
\hline Jász-Nagy kun-Szolnok & 194 & 197 & 101,8 & 0,9 & 0,7 \\
\hline Tolna & 185 & 256 & 138,2 & 0,8 & 0,9 \\
\hline Vas & 414 & 724 & 174,8 & 1,8 & 2,5 \\
\hline Veszprém & 811 & 855 & 105,4 & 3,6 & 3,0 \\
\hline Zala & 402 & 578 & 143,8 & 1,8 & 2,0 \\
\hline Összesen & 22437 & 28508 & 127,1 & 100,0 & 100,0 \\
\hline
\end{tabular}

Forrás: Saját számítás a KSH adatai alapján. 
Bajmócy Péter : A népességszám változás települési és megyei szintü egyenlötlenségeinek néhány mérési lehetösége Magyarországon. Tér és Társadalom 21. évf. 2007/1. 85-102. p.

A növekvő települések népességnövekményének megyénkénti megoszlását vizsgálva számottevő Pest megye elönye (3. táblázat). Az 1995-1999 közötti 53\%-os értékét valamelyest még növelte is a főváros környéke 2001-2004-re, ekkor már a növekvő népességủ települések népességnövekményének 56\%-át koncentrálta Pest megye. A Pest megyét követő megyék (Borsod-Abaúj-Zemplén, Fejér, GyörMoson-Sopron) értékei csak mintegy tizedét teszik ki Pest megyének. Miközben a növekvö települések népességnövekménye országosan 27,1\%-kal több évente 20012004 között, mint 1995-1999 között, addig a dunántúli megyék zömében és Pest megyében ennél gyorsabban növekedett e mutató értéke, ugyanakkor a Dunától keletre csak Nógrád rendelkezik átlag feletti értékkel. A Dunántúl egészében a növekvö népességszámú települések növekménye $41 \%$-kal nőtt a vizsgált időszak alatt, ugyanakkor a Dunától keletre lévő megyékben a növekmény 5\%-kal csökkent. Különösen dinamikus volt a növekedés Baranya, Györ-Moson-Sopron, Komárom-Esztergom, Vas és Zala megyékben, ugyanakkor visszaesés történt Bács-Kiskunban, Békésben és Szabolcs-Szatmár-Beregben.

\section{TÁBLÁZAT}

Az abszolút számban növekvö települések néhány adata 1995-1999, illetve 2001-2004 között (évente), típusonként

Some Data of the Settlements with Increasing Population between 1995-1999 and 2001-2004 [yearly, by settlement-types])

\begin{tabular}{|c|c|c|c|c|c|}
\hline Tipus & $\begin{array}{l}\text { Növekmény } \\
1995-1999\end{array}$ & $\begin{array}{l}\text { Növekmény } \\
2001-2004\end{array}$ & $\begin{array}{l}\text { Változás } \\
\text { (\%) }\end{array}$ & $\begin{array}{c}\text { Részarány } \\
\text { az orszá- } \\
\text { gosból } \\
1995- \\
1999\end{array}$ & $\begin{array}{c}\text { Részarány } \\
\text { az orszá- } \\
\text { gosból } \\
2001- \\
2004\end{array}$ \\
\hline Budapesti agglomeráció & 12011 & 16211 & 135,0 & 53,5 & 56,9 \\
\hline Egyéb agglomerációk & 4941 & 6340 & 128,3 & 22,0 & 22,2 \\
\hline $\begin{array}{l}\text { Egyéb típusok } \\
10 \text { fö alatti növekmény- }\end{array}$ & 3283 & 3534 & 107,6 & 14,6 & 12,4 \\
\hline $\begin{array}{l}\text { nyel rendelkezö } \\
\text { települések }\end{array}$ & 2202 & 2423 & 110,0 & 9,8 & 8,5 \\
\hline$\ddot{\text { sszesen }}$ & 22437 & 28508 & 127,1 & 100,0 & 100,0 \\
\hline \multicolumn{6}{|l|}{$\begin{array}{l}\text { Az egyéb típusok } \\
\text { részletezése: }\end{array}$} \\
\hline Turizmus & 841 & 1286 & 152,9 & 3,7 & 4,5 \\
\hline Periféria & 793 & 904 & 114,0 & 3,5 & 3,2 \\
\hline Cigânyság & 704 & 343 & 48,7 & 3,1 & 1,2 \\
\hline Kisváros & 281 & 276 & 98,2 & 1,3 & 1,0 \\
\hline Nagyváros & 234 & 0 & 0,0 & 1,0 & 0,0 \\
\hline Osztrák határ mente & 217 & 458 & 211,1 & 1,0 & 1,6 \\
\hline Dezurbanizáció & 99 & 185 & 186,9 & 0,4 & 0,6 \\
\hline Egyéb & 114 & 82 & 71,9 & 0,5 & 0,3 \\
\hline
\end{tabular}

Forrás: Saját számítás a KSH adatai alapján. 
Bajmócy Péter : A népességszám változás települési és megyei szintü egyenlőtlenségeinek néhány mérési lehetösége Magyarországon. Tér és Társadalom 21. évf. 2007/1. 85-102. p.

A növekvö népességü települések tipizálását elvégezve látható, hogy a nagyvároskörnyéki települések adják a népességnövekmény zömét. A budapesti agglomeráció települései koncentrálják a növekvő népességszámú települések népességnövekményének 54-57\%-át (1995-1999-ben, illetve 2001-2004-ben), az egyéb agglomerációk pedig 22\%-ot (4. táblázat). A legkisebb, 10 fö alatti éves növekedéssel rendelkezö települések esetében sokszor nem dönthetö el egyértelműen a népességnövekedés oka, így e települések nem kerültek be a tipizálásba. A legfontosabb ok tehát a szuburbanizáció, erre vezethető vissza a növekvő népességú települések népességnövekedésének 75-80\%-a. Ráadásul mind Budapest környéke, mind az egyéb nagyvárosok térsége erösödött is a kilencvenes évek második feléhez képest. Az egyéb típusok között kiemelendők a turisztikai települések (a növekvő népességü települések teljes népességnövekményének 4-5\%-a), a periférikus községek, térségek (3-4\%), valamint a roma népességü, lakosságukat elsősorban természetes szaporodásból növelö települések (1995-1999 között 3\%, 2001-2004 között már csak 1\%). A többi típus részaránya nem számottevő (4. táblázat).

A vidéki agglomerációk növekvő népességszámú településeinek népességnövekménye összesen is csak mintegy $40 \%$-át adja a budapesti agglomerációnak. A legnagyobb vidéki agglomerációk (Győr, Debrecen, Pécs, Székesfehérvár, Szeged, Miskolc) egyenként csak 3-6\%-át adják a budapesti agglomeráció népességnövekményének. Természetesen ez esetben is csak a közigazgatásilag önálló, növekvö népességü települések figyelembe vételére nyílt lehetőség. A hazai településhálózat sajátosságai miatt a szuburbanizáció egy része nem a közigazgatásilag önálló településeket célozza meg, hanem a kiköltöző népesség sok esetben a városok, ritkábban a közeli községek valamely egyéb belterületére avagy külterületére költözik (Kovács 1999, Tímár 1993). Némely város esetében a legdinamikusabban növekvö városkörnyéki települések épp ezek a közigazgatásilag nem önálló egységek (Debrecen-Józsa, Kecskemét-Katonatelep, Nyíregyháza-Oros stb.). E településrészek esetében éves adatokkal nem rendelkezünk, így a szuburbanizáció és az ebböl származó népességnövekmény ezen része a statisztikai adatokból rejtve marad. Az is látható, hogy a megyei jogú városaink egy részénél az önálló településekre irányuló szuburbanizáció léptéke minimális, nyolc megyei jogú városunk esetében a környékükön lévő növekvő népességszámmal rendelkező közigazgatásilag önálló települések népességnövekménye sem 1995-1999, sem 2001-2004 között nem érte el évente a 100 föt. E városok mindegyike relatíve kis népességü (35-65 ezer fös). Az 1995-1999 és 2001-2004-es adatokat összehasonlítva komoly előrelépés figyelhető meg Győr, Pécs, Szombathely, Kecskemét, Eger környékén, ugyanakkor visszaesett a településeket érintő szuburbanizáció mértéke Debrecen, Miskolc, Veszprém², Nyíregyháza és Szolnok térségében. Itt is megfigyelhető tehát a Nyugat-Kelet kettósség, a nyugati nagyvárosok környékén inkább erösödött, a keletieknél stagnált-gyengült a szuburbanizáció a kilencvenes ével második fele és a 2000-es évtized elsö évei között (5. táblázat). 
Bajmócy Péter : A népességszám változás települési és megyei szintü egyenlötlenségeinek néhány mérési lehetösége Magyarországon. Tér és Társadalom 21. évf. 2007/1. 85-102. p.

\section{TÁBLÁZAT}

Az abszolút számban növekvö települések néhány adata 1995-1999, illetve 2001-2004 között (évente), a vidéki agglomerációk részletezése

( Some Data of the Settlements with Increasing Population between 1995-1999 and 2001-2004 [yearly, by the agglomerations of the largest cities])

\begin{tabular}{|c|c|c|c|c|c|}
\hline Tipus & $\begin{array}{l}\text { Növekmény } \\
\text { 1995-1999 }\end{array}$ & $\begin{array}{c}\text { Növek- } \\
\text { mény } \\
2001- \\
2004\end{array}$ & $\begin{array}{l}\text { Válto- } \\
\text { zás (\%) }\end{array}$ & $\begin{array}{c}\text { Rész- } \\
\text { arány az } \\
\text { orszá- } \\
\text { gosból } \\
1995- \\
1999 \\
\end{array}$ & $\begin{array}{c}\text { Rész- } \\
\text { arány az } \\
\text { orszá- } \\
\text { gosból } \\
2001- \\
2004 \\
\end{array}$ \\
\hline Györ & 392 & 1022 & 260,7 & 1,7 & 3,6 \\
\hline Debrecen & 758 & 726 & 95,8 & 3,4 & 2,5 \\
\hline Pécs & 266 & 646 & 242,9 & 1,2 & 2,3 \\
\hline Székesfehérvár & 511 & 537 & 105,1 & 2,3 & 1,9 \\
\hline Szeged & 464 & 507 & 109,3 & 2,1 & 1,8 \\
\hline Miskolc & 454 & 453 & 99,8 & 2,0 & 1,6 \\
\hline Dunaújváros & 308 & 370 & 120,1 & 1,4 & 1,3 \\
\hline Szombathely & 134 & 348 & 259,7 & 0,6 & 1,2 \\
\hline Kecskemét & 166 & 296 & 178,3 & 0,7 & 1,0 \\
\hline Veszprém & 355 & 259 & 73,0 & 1,6 & 0,9 \\
\hline Tatabánya-Tata & 127 & 166 & 130,7 & 0,6 & 0,6 \\
\hline Eger & 59 & 152 & 257,6 & 0,3 & 0,5 \\
\hline Nyíregyháza & 176 & 106 & 60,2 & 0,8 & 0,4 \\
\hline Zalaegerszeg & 56 & 83 & 148,2 & 0,2 & 0,3 \\
\hline Sopron & 62 & 73 & 117,7 & 0,3 & 0,3 \\
\hline Kaposvár & 89 & 68 & 76,4 & 0,4 & 0,2 \\
\hline Szekszárd & 70 & 65 & 92,9 & 0,3 & 0,2 \\
\hline Salgótarján & 0 & 55 & - & 0,0 & 0,2 \\
\hline Szolnok & 120 & 45 & 37,5 & 0,5 & 0,2 \\
\hline Nagykanizsa & 0 & 10 & - & 0,0 & 0,0 \\
\hline Békéscsaba & 11 & 0 & 0,0 & 0,0 & 0,0 \\
\hline Hódmezővásárhely & 0 & 0 & - & 0,0 & 0,0 \\
\hline A „vidéki” agglomerációk & 4941 & 6340 & 128,3 & 22,0 & 22,2 \\
\hline Budapesti agglomeráció & 12011 & 16211 & 135,0 & 53,5 & 56,9 \\
\hline Összesen & 22437 & 28508 & 127,1 & 100,0 & 100,0 \\
\hline
\end{tabular}

Forrás: Saját számítás a KSH adatai alapján.

\section{3. módszer: Mely település nölfogy a leggyorsabban?}

E kérdés elsőre értelmetlennek is tünhet, hiszen a népességszám-változás rátája természetes módon adhatja meg a választ. De vajon mely település fogy gyorsabban? Az, amelyik csak néhány száz föt veszít népességéből, de ez népességének 70-80\%-a, 
Bajmócy Péter : A népességszám változás települési és megyei szintü egyenlötlenségeinek néhány mérési lehetösége Magyarországon. Tér és Társadalom 21. évf. 2007/1. 85-102. p.

vagy az, amelyik elveszít ugyan 4-5000 föt, ám ezzel „csak” 30\%-ot csökken? Vajon Gagyapáti vagy Makó népessége fogyott jobban 1949-1990 között (6. táblázat)? Érdemes lehet az arányokat és az abszolút számokat is együtt vizsgálni.

Célszerünek tủnt tehát a két mutatót, az abszolút és a relatív népességfogyást kombinálni és létrehozni egy „kombinált népességfogyási mutatót”. E mutatót nagyon egyszerüen a két alapmutatónk szorzataként értelmeztük.

Amennyiben a település népessége a kezdeti időpontban: a, a végső időpontban: b, a népességszámváltozási mutató értéke:

$$
\text { NVMUT }=a b s(b-a) *(b-a) / a / 100
$$

E mutató alapján Battonya esetében (1949: 12666 fö, 1990: 7385 fö), a népesség vesztéség 5.281 fö, 41,7\%, a kombinált mutató értéke pedig $5.281 *(-41,7) / 100=-2202$. Azért, hogy a fogyó területi egységek negatív, a növekvők pedig pozitív értéket kapjanak, a népességváltozás abszolút adatait abszolút értékben számítottuk. A százzal való osztás jelentősége elsősorban technikai, a túl nagy számértékek elkerülése céljából alkalmaztuk. E mutató alapján Gagyapáti és Makó öszehasonlításaként Makó népességfogyása adódott nagyobbnak (6. táblázat).

\section{TÁBLÁZAT}

A népességváltozási mutató értéke néhány településen 1949-1990 között (The Population Change Index in Some Selected Settlements [1949-1990])

\begin{tabular}{llrrrrr}
\hline Település & \multicolumn{1}{c}{ Megye } & $\begin{array}{c}\text { Népesség } \\
1949\end{array}$ & $\begin{array}{c}\text { Népesség } \\
1990\end{array}$ & $\begin{array}{c}\text { Népvált } \\
\left(f^{\prime \prime}\right)\end{array}$ & $\begin{array}{c}\text { Népvált } \\
(\%)\end{array}$ & $\begin{array}{c}\text { NV- } \\
\text { mutató }\end{array}$ \\
\hline Gagyapáti & Borsod-A.-Z. & 236 & 19 & -217 & $-91,9$ & -200 \\
Libickozma & Somogy & 1023 & 82 & -941 & $-92,0$ & -866 \\
Makó & Csongrád & 33068 & 27529 & -5539 & $-16,8$ & -928 \\
Mezőhék & Jász-N.-Sz. & 2302 & 512 & -1790 & $-77,8$ & -1392 \\
Battonya & Békés & 12666 & 7385 & -5281 & $-41,7$ & -2202 \\
\hline
\end{tabular}

Forrás: Saját számítás a KSH adatai alapján.

E mutató segítségével két időszakra a tömeges urbanizáció és a szocializmus időszakának tekinthető 1949-1990-re, valamint a rendszerváltás utáni, a szuburbanizációval jellemezhető egy évtizedre (1990-2001) vizsgáltuk a leggyorsabban növekedö, illetve fogyó népességủ településeket. Az 1949-1990 közötti időszakban leggyorsabban egyes szocialista városok (Dunaújváros, Kazincbarcika, Tiszaújváros, stb.), megyeszékhelyek (Székesfehérvár, Debrecen, Veszprém) és a főváros népessége növekedett, ez időszak legnagyobb vesztesei ugyanakkor a népes kismezövárosok, tanyaközségek voltak, szinte kizárólagosan az Alföldröl (7. táblázat). 
Bajmócy Péter : A népességszám változás települési és megyei szintü egyenlötlenségeinek néhány mérési lehetösége Magyarországon. Tér és Társadalom 21. évf. 2007/1. 85-102. p.

\section{TÁBLÁZAT}

A legmagasabb és legalacsonyabb népességszámváltozási-mutatóval rendelkezö települések 1949-1990

(Settlements with the Highest and Lowest Population Change Index [1949-1990])

\begin{tabular}{|c|c|c|c|c|c|c|c|}
\hline$N R$ & Településnév & Megye & $\begin{array}{c}\text { Népesség } \\
1949\end{array}$ & $\begin{array}{c}\text { Népesség } \\
1990\end{array}$ & $\begin{array}{c}\text { Népvált } \\
\text { (fó) }\end{array}$ & $\begin{array}{c}\text { Népvált } \\
\text { (\%) }\end{array}$ & $\begin{array}{c}N V- \\
\text { mutató }\end{array}$ \\
\hline 1 & Dunaújváros & Fejér & 3949 & 59028 & 55079 & 1394,8 & 768219 \\
\hline 2 & Kazincbarcika & $\begin{array}{l}\text { Borsod- } \\
\text { A.-Z. }\end{array}$ & 3846 & 35692 & 31846 & 828,0 & 263694 \\
\hline 3 & Tiszaújváros & $\begin{array}{l}\text { Borsod- } \\
\text { A.-Z. }\end{array}$ & 1349 & 18685 & 17336 & 1285,1 & 222785 \\
\hline 4 & Százhalombatta & Pest & 1717 & 16573 & 14856 & 865,2 & 128539 \\
\hline 5 & Budapest & Budapest & 1590316 & 2016774 & 426458 & 26,8 & 114359 \\
\hline 6 & Székesfehérvár & Fejér & $42260^{\circ}$ & 108958 & 66698 & 157,8 & 105268 \\
\hline 7 & Komló & Baranya & 5812 & 29143 & 23331 & 401,4 & 93657 \\
\hline 8 & Veszprém & Veszprém & 20682 & 63867 & 43185 & 208,8 & 90172 \\
\hline 9 & Debrecen & Hajdú-B. & 115399 & 212235 & 96836 & 83,9 & 81259 \\
\hline 10 & Oroszlány & $\begin{array}{l}\text { Komárom- } \\
\text { E. }\end{array}$ & 3740 & 20982 & 17242 & 461,0 & 79488 \\
\hline 3126 & Jászladány & $\begin{array}{l}\text { Jász-N.- } \\
\text { Sz. }\end{array}$ & 9377 & 6028 & -3349 & $-35,7$ & -1196 \\
\hline 3127 & Mezőhék & $\begin{array}{l}\text { Jász-N.- } \\
\text { Sz. }\end{array}$ & 2302 & 512 & -1790 & $-77,8$ & -1392 \\
\hline 3128 & Dévaványa & Békés & 13196 & 8842 & -4354 & $-33,0$ & -1437 \\
\hline 3129 & Öcsöd & $\begin{array}{l}\text { Jász-N.- } \\
\text { Sz. }\end{array}$ & 7405 & 4125 & -3280 & $-44,3$ & -1453 \\
\hline 3130 & Ozora & Tolna & 4678 & 1977 & -2701 & $-57,7$ & -1560 \\
\hline 3131 & Kunágota & Békés & 6380 & 3197 & -3183 & $-49,9$ & -1588 \\
\hline 3132 & Borota & $\begin{array}{l}\text { Bács- } \\
\text { Kiskun }\end{array}$ & 4444 & 1777 & -2667 & $-60,0$ & -1601 \\
\hline 3133 & Ásotthalom & Csongrád & 8062 & 4106 & -3956 & $-49,1$ & -1941 \\
\hline 3134 & Bácsszőlős & $\begin{array}{l}\text { Bács- } \\
\text { Kiskun }\end{array}$ & 3146 & 519 & -2627 & $-83,5$ & -2194 \\
\hline 3135 & Battonya & Békés & 12666 & 7385 & -5281 & $-41,7$ & -2202 \\
\hline
\end{tabular}

Forrás: Saját számítás a KSH adatai alapján.

A növekvő települések ez idő tájt elsősorban a városok, az energiatengely településeinek jelentős része, valamint Budapest agglomerációja. Ugyanakkor az alföldi községek, kisvárosok zöme fogyott, miként az aprófalvak legnagyobb része is. Egyes térségekben, külső és belső perifériákon szinte kizárólagosak voltak a fogyó, gyorsan fogyó települések (Börzsöny, Cserehát, Zempléni-hegység, Bodrogköz, Szatmár-Bereg, Bihar, Közép-Tiszavidék, Dél-Békés, Bácska, Somogy-Tolna határvidéke, Zala, Dél-Kisalföld) (6. ábra). 
Bajmócy Péter : A népességszám változás települési és megyei szintü egyenlötlenségeinek néhány mérési lehetősége Magyarországon. Tér és Társadalom 21. évf. 2007/1. 85-102. p.

TÉT XXI. évf. 2007 - 1 A népességszám változás települési és ...

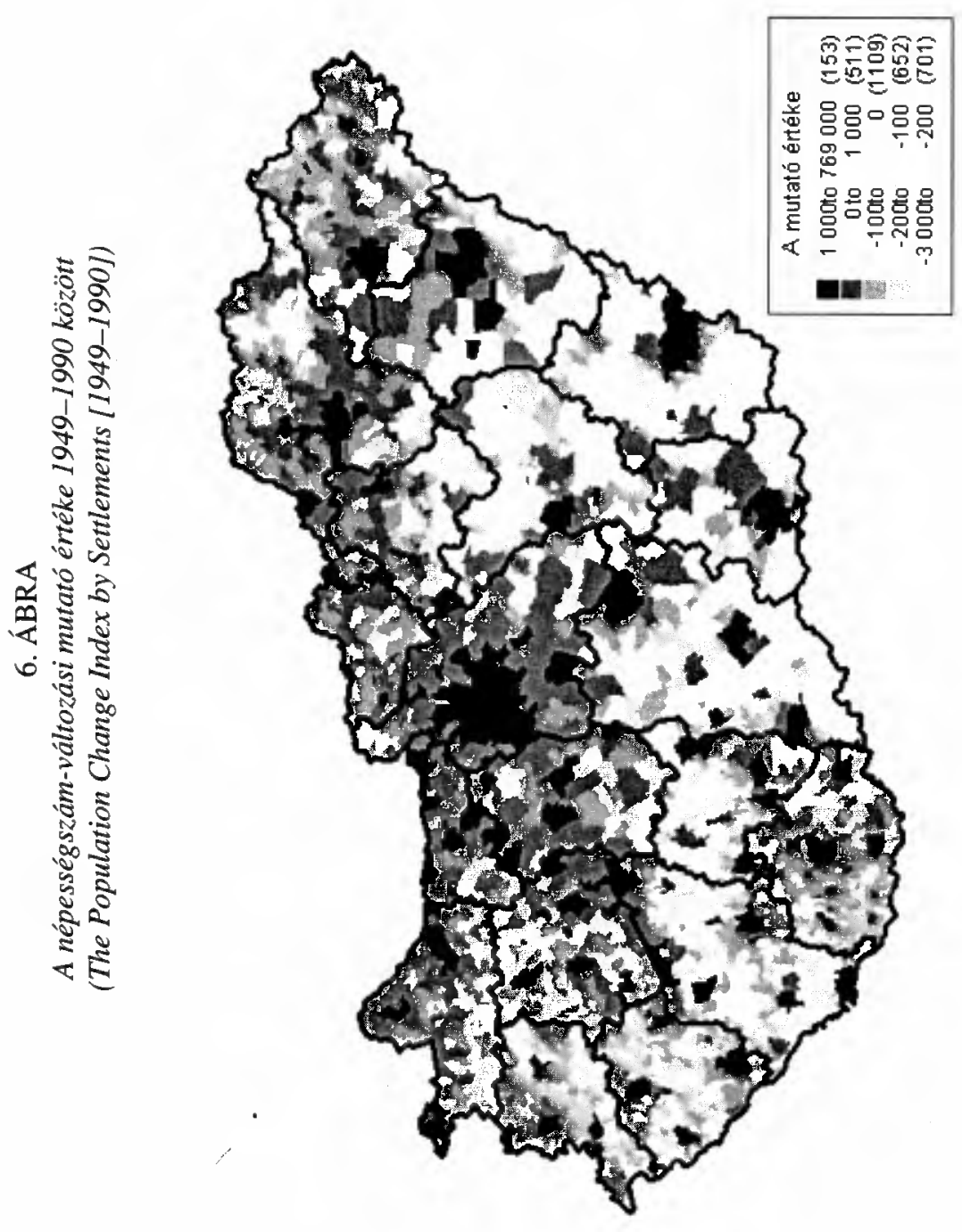

葛 
Bajmócy Péter : A népességszám változás települési és megyei szintü egyenlötlenségeinek néhány mérési lehetösége Magyarországon. Tér és Társadalom 21. évf. 2007/1. 85-102. p.

1990-2001 között a domináns tényező a szuburbanizáció lett. A leggyorsabban növekvő települések mindegyike nagyváros (zömében Budapest) környéki, ugyanakkor a leginkább fogyó települések kivétel nélkül városok, közöttük megyeszékhelyek, iparvárosok és néhány középváros (Orosháza, Gyöngyös) található (8. táblázat). Néhány telepüiés (Dunaújváros, Kazincbarcika, Budapest) az urbanizáció idószakában a leggyorsabban növekvő, napjainkban a leginkább fogyó települések között vannak.

\section{TÁBLÁZAT}

A legmagasabb és legalacsonyabb népességváltozási-mutatóval rendelkezö települések, 1990-2001

(Settlements with the Highest and Lowest Population Change Index [1990-2001])

\begin{tabular}{|c|c|c|c|c|c|c|c|}
\hline$N R$ & Településnév & Megye & $\begin{array}{c}\text { Népesség } \\
1990\end{array}$ & $\begin{array}{c}\text { Népesség } \\
2001\end{array}$ & $\begin{array}{c}\text { Népvált } \\
\text { (fö) }\end{array}$ & $\begin{array}{c}\text { Népvált } \\
(\%)\end{array}$ & $\begin{array}{c}N V- \\
\text { mutató }\end{array}$ \\
\hline 1 & Érd & Pest & 43327 & 56567 & 13240 & 30,6 & 4046 \\
\hline 2 & Telki & Pest & 629 & 1892 & 1263 & 200,8 & 2536 \\
\hline 3 & Veresegyház & Pest & 6373 & 10256 & 3883 & 60,9 & 2366 \\
\hline 4 & Hajmáskér & Veszprém & 1306 & 2900 & 1594 & 122,1 & 1946 \\
\hline 5 & Tököl & Pest & 6308 & 9559 & 3251 & 51,5 & 1675 \\
\hline 6 & Bocskaikert & Hajdú-B. & 1145 & 2410 & 1265 & 110,5 & 1398 \\
\hline 7 & Solymár & Pest & 6044 & 8912 & 2868 & 47,5 & 1361 \\
\hline 8 & Diósd & Pest & 3719 & 5785 & 2066 & 55,6 & 1148 \\
\hline 9 & Hajdúsámson & Hajdú-B. & 7734 & 10677 & 2943 & 38,1 & 1120 \\
\hline 10 & Nagykovácsi & Pest & 3323 & 5244 & 1921 & 57,8 & 1111 \\
\hline 3126 & Salgótarján & Nógrád & 47822 & 44964 & -2858 & $-6,0$ & -171 \\
\hline 3127 & Eger & Heves & 61892 & 58331 & -3561 & $-5,8$ & -205 \\
\hline 3128 & Orosháza & Békés & 34526 & 31764 & -2762 & $-8,0$ & -221 \\
\hline 3129 & Gyöngyös & Heves & 36451 & 33548 & -2903 & $-8,0$ & -231 \\
\hline 3130 & Dunaújváros & Fejér & 59028 & 55309 & -3719 & $-6,3$ & -234 \\
\hline 3131 & Ózd & $\begin{array}{l}\text { Borsod- } \\
\text { A. }-Z \text {. }\end{array}$ & 41561 & 38405 & -3156 & $-7,6$ & -240 \\
\hline 3132 & Kazincbarcika & $\begin{array}{l}\text { Borsod- } \\
\text { A.-Z. }\end{array}$ & 35692 & 32356 & -3336 & $-9,3$ & -312 \\
\hline 3133 & Pécs & Baranya & 170039 & 162498 & -7541 & $-4,4$ & -334 \\
\hline 3134 & Miskolc & $\begin{array}{l}\text { Borsod- } \\
\text { A.-Z. }\end{array}$ & 196442 & 184125 & -12317 & $-6,3$ & -772 \\
\hline 3135 & Budapest & Budapest & 2016774 & 1777921 & -238853 & $-11,8$ & -28288 \\
\hline
\end{tabular}

Forrás: Saját számítás a KSH adatai alapján.

A növekvő települések 1990-2001 között elsősorban a nagyvárosok környékén tałálhatók, emellett néhány osztrák határ menti település, valamint kevés periférikus község (Cserehát, Szabolcs, Szatmár) népességváitozási mutatója is kiemelkedö. Ugyanakkor a perifériák zöme továbbra is veszít népességéböl, ám emellett a legtöbb nagy- és középváros, valamint az alföldi közép- és kisvárosok népességváltozási mutatója is negatív (7. ábra). 
Bajmócy Péter : A népességszám változás települési és megyei szintū egyenlőtlenségeinek néhány mérési lehetösége Magyarországon. Tér és Társadalom 21. évf. 2007/1. 85-102. p.

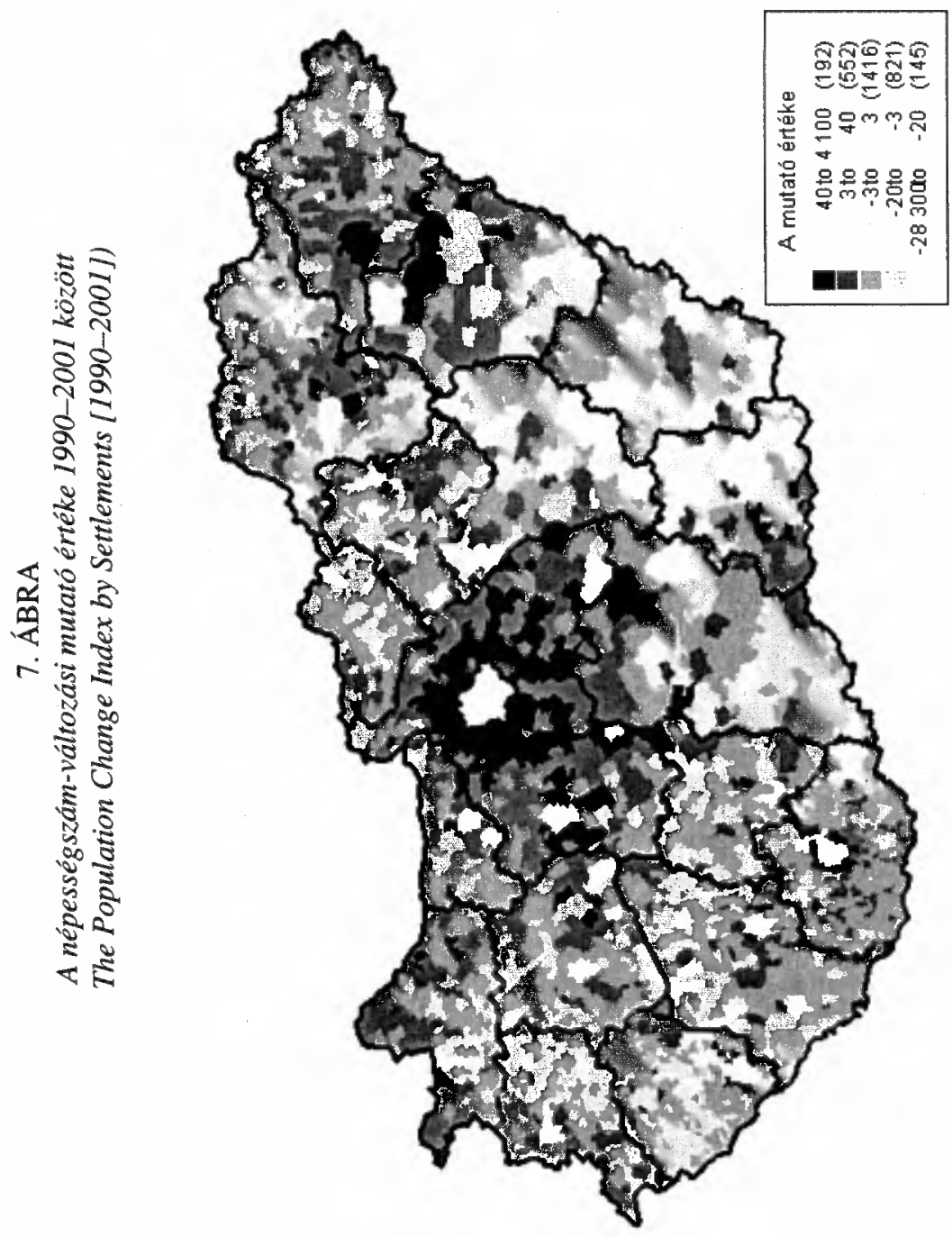

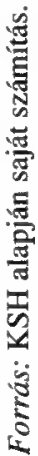


Bajmócy Péter : A népességszám változás települési és megyei szintű egyenlőtlenségeinek néhány mérési lehetösége Magyarországon. Tér és Társadalom 21. évf. 2007/1. 85-102. p.

\section{Jegyzetek}

1 A tanulmány a 2006. november 18-án, az ELTE-n tartott Regionális Modellek c. tudományos konferencián elhangzott elöadásra épüil.

2 Veszprém esetében Hajmáskér okozza a visszaesést, 1995 -1999 között évente 147, 2001-2004 között 48 fövel nött a lakossága. A kilencvenes évek növekedésének oka a katonai bázis lakóteleppé alakítása volt.

\section{Irodalom}

Bajmócy P. (1999) A kistérségek népességváltozási tendenciái Magyarországon. - Társadalomföldrajzi vizsgálatok két évezred találkozásánál. Szeged. 57-77. o.

Bajmócy P. (2000) A természetes szaporodás területi kủlönbségei Magyarországon az elmúlt három évtizedben. - Geográfus doktoranduszok III. országos konferenciája kötete. DE TTK, Debrecen. 222-230. o.

Beluszky P. (1999) Magyarország településföldrajza. Általános rész. Dialóg-Campus Kiadó, Budapest-Pécs.

Beluszky P.-Sikos T.T. (1982) Magyarország falutípusai. MTA FKI, Budapest.

Kovács Z. (1999) Alföldi nagyvárosok társadalmi szerkezetének vizsgálata. - Alfóldi Tanulmányok 1998-1999. Nagyalföld Alapítvány, Békéscsaba. 52-72. o.

Timár J. (1993) Az alföldi szuburbanizáció néhány sajátossága. - Alfóldi Tanulmányok. 217-232. o.

\section{SOME QUANTITATIVE METHODS MEASURING THE DISEQUALITIES OF THE POPULATION CHANGE IN THE HUNGARIAN SETTLEMENTS AND COUNTIES}

\section{PÉTER BAJMÓCY}

The population changing processes of the Hungarian settlements are relatively well-known, but with some special quantiative methods we can give further details in this topic. In this article we tried to use three quantitative methods to descibe the details of the population changes of the settlements. In the first method we created settlement types with the combination of the population change and the migration balance. Secondly we investigated the role of the different settlemnt types (suburban villages, touristic attractions, roma villages, etc.) among the settlements with increasing population. Thirdly we created a so called ,population change index" with the combination of the population change by absolute number and by rates. With this index we can sort the most dynamic and the fastest decreasing settlements. 